\title{
Is your biotech giving away the store?
}

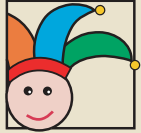

Tom Jacobs, of the Internet site Motley Fool (http://www.fool. com/), provides his angle on biotechnology investments. Read on and become "Foolishly" informed*. He can be contacted about biotechnology and investing at TomJ@Fool.com Jacobs cannot give individual investment advice but welcomes any.

The Sitting Pretty Investment Club was in a feisty mood, drawing attention during their regular meeting at the Bull \& Bear pub. The subject? Companies that grant a huge percentage of employee stock options (ESOs).

"It's criminal!" Clyde Goforth said indignantly, though his techie garb of shorts and sandals made indignation hard to pull off. "It's like mutual fund expenses. If your mutual fund pays $2 \%$ a year in expenses, its stock portfolio must rise $2 \%$ just for you to stay even. Similarly, if a company whose shares you own grants 3\% of outstanding shares in the form of ESOs each year, its stock has to rise $3 \%$ for a shareholder to stay in the same place."

Interim President Paisley McTort felt uneasy. "Goforth, my good man, I don't think I truly understand the evil here." General (Retd.) Blatsworthy sniffed, "I have no problem with rewarding management."

Undaunted, Goforth sped on. "Let's take 'Jack Horner Pies' (Ticker: THUMB). You own one of its four shares of stock. Think of the company as one of its own scrumptious coconut cream pies cut into four pieces representing the four shares of stock. The company grants another share to the CEO or other employee in the form of a stock option. Assuming that the CEO exercises her option to purchase the share, whether she holds or sells it, there are now five shares outstanding. The same pie is now cut into five parts. As your precocious child will tell you, your share is worth $20 \%$ less.

"But Jack Horner is having a good year and increases its earnings a sweet $25 \%$. Your share

\footnotetext{
* Nature Biotechnology does not guarantee the veracity, reliability, or completeness of any information provided on this page; it is not responsible for any errors or omissions or for any results obtained from the use of such information; it will not be liable for any loss, damage, or investment decision arising from a reader's reliance on the information provided.
}

of business ownership is worth more. Problem is, your share is now the size it was before the grant to the CEO. Despite a stellar year at the company, you're only even.

"Of course, in practice, not all ESOs will actually be exercised. Companies may cancel options or employees may leave before their options vest. And

Table 1. Stock option grants-top ten biotechs by market cap* Percentage of shares granted as stock options for financial year

\begin{tabular}{lccc}
\hline Company & FY 2001 & FY 2000 & FY 1999 \\
\hline Amgen & $1.3 \%$ & $1.8 \%$ & $1.6 \%$ \\
Genentech & $2.0 \%$ & $1.9 \%$ & $3.3 \%$ \\
Chiron & $3.7 \%$ & $3.8 \%$ & $2.5 \%$ \\
Gilead Sciences & $3.3 \%$ & $1.6 \%$ & $0.9 \%$ \\
IDEC Pharmaceuticals & $2.6 \%$ & $3.6 \%$ & $1.4 \%$ \\
Medimmune Pharmaceuticals & $2.2 \%$ & $3.4 \%$ & $1.2 \%$ \\
Genzyme General & $3.2 \%$ & $1.3 \%$ & $1.8 \%$ \\
Biogen & $2.6 \%$ & $1.8 \%$ & $2.0 \%$ \\
Millennium Pharmaceuticals & $4.6 \%$ & $7.2 \%$ & $2.6 \%$ \\
Cephalon & $4.1 \%$ & $4.2 \%$ & $2.0 \%$ \\
\hline
\end{tabular}

*Non-US biotech companies are not included because their information is less readily available. the stock price of some options may stay 'underwater'-well below the option exercise price, though companies sometimes just reprice them. But tracking the ESO grants tells you important things about how management treats your ownership share.

Goforth consulted his Palm Pilot. "Let's take the top ten biotechnology companies by market capitalization and see how they fare."

Goforth observed, "As investors, we want established, profitable companies to issue fewer than 3\% of shares in ESOs, and developing companies that can't pay higher salaries and whose employees face more risk to issue $5 \%$ or fewer. In 2001, we see that Chiron and Genzyme exceeded the mark slightly for established companies, whereas unprofitable developing companies, such as Cephalon and Millennium, stayed under the $5 \%$ guidelines. For Millennium, that was a marked improvement from a dismal $7.2 \%$ grant in 2000 .

"To compare, developing companies like Human Genome Sciences and Vertex Pharmaceuticals issued $5.3 \%$ and $5.8 \%$ of outstanding shares in ESOs in 2001, whereas elder statespersons Johnson \& Johnson and Pfizer issued a scant $0.2 \%$ and $0.3 \%$, respectively. As a shareholder of these companies, you started out the year down $5 \%$ or so with the former, and with hardly a dent from the latter."

He had won Blatsworthy over. "These are not insignificant numbers. But how does a duffer like me find them?"

Goforth smiled. "Some companies provide easy-to-understand tables of annual ESO grants, cancellations, and exercises in their annual report Form 10-K filed with the US Securities \& Exchange Commission. For those that do not, consult the company's most recent Proxy Statement Form 14A and do a little basic math. In the Executive Compensation section, there will be entries for Options Grants during the year, and each will say what percentage of the total ESOs it represents. Divide an ESO grant by the percentage, and you have the total number of ESOs granted for the year. Next, find the company's basic shares outstanding at the end of the year, available in the income statement of its annual report-Form 10K. Divide the number of ESOs granted by the basic share number, and voila! That's the percentage given away in ESOs.

"Using Jack Horner an example, we find that in 2001 its $14 \mathrm{~A}$ proxy statement reveals it issued 200,000 ESOs to its eponymous CEO, Little Jack Horner, because he had been such a good little boy. That was $5 \%$ of the total issued to company employees, or 4 million. Jack Horner Pies' Form 10K for fiscal 2001 showed 100 million basic shares outstanding. By issuing those options, the company diluted current owners by $4 \%$."

Blatsworthy offered grudging approval. "But where do I find these forms?"

Finally, Paisely McTort could offer something. He added, "They are easily available online through the SEC website, http://www.Fool.com, or other online financial resources."

Blatsworthy ordered another round to signal the end of the business portion of the meeting. "Goforth, I feel better armed for the investing war than in any of my great battles, though did I ever tell you about my tour in North Africa? There was a challenge. It began calmly enough, but..."

As the tale began, Club members waited for their new drinks. Then they exercised their own options - to leave quietly. 